\title{
An Evaluation of the Chemical Composition and Antibacterial Activities of Mormodica balsamina Seeds Extract
}

\author{
Uchegbu RI ${ }^{1 *}$, Bako SS ${ }^{2}$, Amanze $\mathrm{KO}^{1}$ and Igara $\mathrm{CE}^{3}$ \\ ${ }^{1}$ Department of chemistry, Alvan Ikoku Federal College of Education, Nigeria \\ ${ }^{2}$ Department of chemistry, Kaduna State University, Nigeria \\ ${ }^{3}$ Department of science laboratory technology, Akanu Ibiam Federal Polytechnique, Nigeria
}

Submission: May 15, 2017 , Published: June 05, 2017

*Corresponding author: Uchegbu RI, Department of Chemistry, Alvan Ikoku Federal College of Education, Owerri, Imo State, Nigeria, Email: mrsriu@yahoo.com

\begin{abstract}
The chemical composition of the seed extract of Mormodica balsamina and its antibacterial activity against some human pathogens were studied. The study was designed to identify the phytochemical and nutritive values of the seeds and to test the inhibitory ability of the plant extract on human pathogens. Chemical composition of Mormodica balsamina seeds was determined using standard methods. The antibacterial activity was performed by filter paper disc diffusion technique. Phytochemical studies revealed the presence of alkaloids (0.34\%), flavonoids $(1.08 \%)$, tannins $(0.28 \%)$, phenols $(0.65 \%)$ and saponins $(2.20 \%)$. The mineral constituents were $\mathrm{Ca}(1.76 \%), \mathrm{Mg}(1.10 \%), \mathrm{K}(0.83 \%), \mathrm{Na}$ $(0.20 \%), \mathrm{P}(0.34 \%)$ and $\mathrm{N}(1.40 \%)$. The plant samples were found to be rich in vitamins comprising riboflavin $(0.30 \mathrm{mg} / 100 \mathrm{~g})$, thiamin $(0.09 \mathrm{mg} / 100 \mathrm{~g})$, niacin $(0.21 \mathrm{mg} / 100 \mathrm{~g})$ and ascorbic acid $(4.44 \mathrm{mg} / 100)$. The proximate composition revealed the presence of protein $(8.75 \%)$, crude fibre (1.95\%), fats/oil (1.45\%), ash (4.50\%), carbohydrates (83.35\%) and food energy (381.5g/cal). The ethanol extract inhibited all the tested organisms E.coli., K. pneumonia, S. aureus, P. mirabilis and Salmonina indicating that Mormodica balsamina seeds can serve as a potential food and antibacterial agents.
\end{abstract}

Keywords: Mormodica balsamina; Phytochemical; Human pathogens

Abbreviations: MDR: Multidrug Resistant; DMSO: Dimethyl Sulphoxide

\section{Introduction}

Medicinal plants have been recognized to be of great importance to the health of individuals and communities. The efficacy of these plants in treatment of ailments has encouraged researchers into finding solutions to treatment of many diseases. In many developing countries, herbal medicines are assuming greater importance in primary health care and their International trade has increased though many of the herbal products are not registered by national regulatory bodies [1].

The antimicrobial compounds found in plants are of interest because of the emergence of multidrug resistant (MDR) bacteria, which is a major cause of treatment failure in many infectious diseases and which is becoming a worldwide public health concern. Thus, naturally occurring antimicrobials are being sought as replacements for synthetic ones. Green plants have been discovered to be the source of many useful compounds.

Nigeria is blessed with many of such plants which include Mormodica balsamina linn. Mormodica balsamina linn also known as balsam apple or African pumpkin is a climber with stem attaining 4-5mm in length [1]. It belongs to the family of cucurbitaleae. The plant is a perennial herb with soft stems and tendrils. The plant produces spindle shaped fruits (dark green when unripe and bright to deep orange when ripe). The seeds are embedded into a sweet edible red fleshy pulp that test like water melon [2]. The whole plant is used as a bitter stomachic and its infusion is used as a wash in the management of fever and yaws [3]. A macerate of the whole plant is also used as a galactogogue and to massage the chest to relieve intercostals 
pains [1]. The roots and stems of M. balsamina are used for the treatment of diarrhea [4]. In Northern part of Nigeria, the leaves are cooked as green vegetable soup for lactating mother, where it is believed to help the mother regain or regenenerate her lost blood during labor and to purify her breast milk [5-7]. Work carried out by revealed that $M$. balsamina plant contains a therapeutic agent 'Momordin' which is capable of inhibiting the growth of HIV and other viruses.

In spite of the usefulness of this plant, much work has not been done on this lesser -known, underutilized but vital plant. Thus the researchers tend to determine the chemical composition and tha antibacterial activity of the seeds of Mormodica balsamina to ascertain their usefulness as a potential food and antibacterial agent.

\section{Materials and Method}

\section{Plant materials/sample preparation}

Momordica balsamina was collected from forests in keffi, Nassarawa state, Nigeria. Authentication of plant materials was done by Dr A. Nmeregini of Taxonomy section, Forestry Department, Michael Okpara University of Agriculture, and Umudike, Nigeria. The fresh seeds were ground and used for analysis.

\section{Chemical analysis}

The phytochemical were determined according to the method described by [8]. The macro elements, calcium, sodium, potassium, phosphorus, magnesium were determined according to the method described by [9]. The vitamin $\mathrm{C}$ and $B$ complexes (thiamin, riboflavin and niacin) were determined according to. Total nitrogen $(\mathrm{N})$ content was determined by the use of a micro Kjeldahl MD 55 (Singapore) apparatus. The protein content was calculated as $\mathrm{N}$ x 6.25. Crude fiber, Fats/oil and ash content were determined according to [10]. Total Carbohydrates were estimated as the remainder after accounting for ash, crude fiber, Protein and fats/oil and the gross food energy was estimated according to the method of by using the equation.

$\mathrm{FE}=(\% \mathrm{CP} \times 4)+(\% \mathrm{CHO} \times 4)+(\% \mathrm{Fat} \times 9)$.

Where FE=Food energy (in g/cal), CP=Crude Protein, $\mathrm{CHO}=$ Carbohydrates.

\section{Anti-bacterial evaluation of the seeds of momordica balsamina}

Preparation of extracts: The test solution of each extract was prepared by dissolving $0.1 \mathrm{~g}$ of the plant extracts separately in $1.0 \mathrm{ml}$ of dimethyl sulphoxide (DMSO) to get a concentration of $100 \mathrm{mg} / \mathrm{ml}$.

Micro-organisms: The bacteria organisms used were Staphylococus aureus, Klebsiella pneumonia, Salmonina, Proteus mirabilis and Escherichia coli. All the organisms were obtained from the stock culture of the Federal Medical Center, Umuahia. Cultures were brought to laboratory conditions by resuscitating the organisms in peptone water and thereafter sub cultured into nutrient agar medium and incubated at $37{ }^{\circ} \mathrm{C}$ for 24 hours.

Antibacterial assay: The antibacterial activity was performed by filter paper disc diffusion technique. Filter paper disc (whattman No1, 6mm diameter) were placed in glass Petri dishes and sterilized in hot air oven [11]. The media $(10 \mathrm{~g}$ nutrient agar in $200 \mathrm{ml}$ distilled water, auto-claved at $115^{\circ} \mathrm{C}$ for 30 minutes) was cooled to $50{ }^{\circ} \mathrm{C}$. The sterile nutrient agar media were poured into the sterile petri dishes and allowed to solidify. The bacteria were swabbed with a sterile wire loop. Each disc was impregnated with $0.2 \mathrm{ml}$ of plant extracts and standard- Ciprofloxacin. Discs with DMSO $(100 \mathrm{mg} / \mathrm{ml})$ served as a control.

The discs were used after drying them in an incubator at 40 ${ }^{\circ} \mathrm{C}$ to remove any trace of solvent [11]. Discs were introduced onto the surface of the medium. The plates were incubated at 37 ${ }^{\circ} \mathrm{C}$ for 24 hours to obtain zones of inhibition. The experiments were repeated three times for each extract and twice for reference antibiotic to minimize error and the average of these values were tabulated in.

Minimum inhibitory concentration (MIC): The minimum inhibitory concentration of the extracts was determined by incorporating constant volumes $(0.2 \mathrm{ml})$ of each dilution of the extract into the perforated discs on a seeded nutrient agar plate as described in the antimicrobial susceptibility testing section [12]. $0.1 \mathrm{~g}$ of each extract was dissolved in $1 \mathrm{ml}$ of DMSO to obtain $100 \mathrm{mg} / \mathrm{ml}$. This $100 \mathrm{mg} / \mathrm{ml}$ concentration was then doubly diluted in DMSO to obtain concentration of $50 \mathrm{mg} / \mathrm{ml}$, $25 \mathrm{mg} / \mathrm{ml}, 12.5 \mathrm{mg} / \mathrm{ml}$ and $6.25 \mathrm{mg} / \mathrm{ml}$.

Statistical Analysis: All values are expressed as mean \pm S.D. Statistical analysis were performed by Student's t-test. The values of $p$ lower than 0.05 were considered significant.

\section{Results and Discussions}

Table 1: Phytochemical Composition of seeds of Momordica balsamina expressed as percentages (\%), Values are means of triplicate determinations \pm standard error.

\begin{tabular}{|c|c|}
\hline Constituents & Seeds \\
\hline Alkaloids & $0.34 \pm 0.02$ \\
\hline Flavonoids & $1.08 \pm 0.15$ \\
\hline Tannins & $0.28 \pm 0.01$ \\
\hline Phenols & $0.65 \pm 0.02$ \\
\hline Saponins & $2.20 \pm 0.10$ \\
\hline
\end{tabular}

The seeds of M. balsamina contain $0.34 \%$ of alkaloid. Many plants have been reported to contain alkaloids. Alkaloids isolated from plants are used as basic medicinal agents for their analgesic, antispasmodic and anti-bacterial effects $[13,14]$. 


\section{Recent Advances in Petrochemical Science}

This may be the reason the plant is used in herbal medicine to treat malaria, stomach ache, fever and headache. The seeds of $M$. balsamina contain flavonoids (1.08\%). Flavonoids are known to possess antioxidant property, protect against allergies, inflammation, microbes, ulcer, viruses and tumor (Table 1). Flavonoids are also known to prevent oxidative cell damage, have strong anti-cancer activity and inhibit all stages of carcinogenesis [14].

Tannin which is another important phytochemical was found to be in the $0.28 \%$ in the seeds Tannins are organic substances of diverse composition with pronounced astringent properties that promote the healing of wounds and inflamed mucous membranes [13]. Tannin gives a slight bitter taste to food, and so can counterbalance too much acidity [14]. It can also be effective in protecting the kidney (Table 2).

Table 2: Mineral Composition of seeds of Momordica balsamina expressed in percentages (\%), Values are means of triplicate determinations \pm standard error

\begin{tabular}{|c|c|}
\hline Elements & Seeds \\
\hline Magnesium & $1.10 \pm 0.01$ \\
\hline Calcium & $1.76 \pm 0.02$ \\
\hline Potassium & $0.83 \pm 0.20$ \\
\hline Sodium & $0.20 \pm 0.01$ \\
\hline Phosphorus & $0.34 \pm 0.12$ \\
\hline Nitrogen & $1.40 \pm 0.03$ \\
\hline
\end{tabular}

The seeds of $M$. balsamina contain phenol (0.65\%). Plants that contain phenols could be used as anti-inflammatory, immune enhancers and hormone modulators [15]. Phenols are also known to have the ability to block specific enzymes that cause inflammation and to prevent diseases [14]. Saponins were also found in the seeds (2.20\%) of M. balsamina. Saponins are known to make the bronchial secretion more liquid, reduce the congestion of the bronchi and ease coughing [16]. The high saponin content of the seeds indicate that the extracts from the plants can be used to stop bleeding and in treating wounds. The seeds of M. balsamina contain $1.76 \%$ calcium. Phosphorus was found in the seeds $(0.34 \%)$. Calcium and Phosphorus are needed for bone and teeth formation (Table 3). Phosphorus is also good for kidney function [17].

Table 3: Vitamin Composition of seeds of Momordica balsamina $(\mathrm{mg} / 100 \mathrm{~g})$. Values are means of triplicate determinations \pm standard error.

\begin{tabular}{|c|c|}
\hline Constituents & Seeds \\
\hline Riboflavin & $0.30 \pm 0.03$ \\
\hline Thiamin & $0.09 \pm 0.01$ \\
\hline Niacin & $0.21 \pm 0.03$ \\
\hline Ascorbic acid & $4.44 \pm 0.01$ \\
\hline
\end{tabular}

Magnesium, another important mineral was also found in the seeds (1.10\%). Magnesium helps to reduce cholesterol [18].
Sodium and potassium which are needed in the blood fluid and in nerves were also found in seeds of $M$. balsamina. $0.20 \%$ of sodium and $0.83 \%$ of potassium were also found in the seeds. The seeds of $M$. balsamina contain $4.44 \mathrm{mg} / 100 \mathrm{~g}$ of Ascorbic acid (Vitamin $\mathrm{C}$ ). Vitamin $\mathrm{C}$ traps radicals formed in aqueous environments, preventing harmful oxidation reactions the radicals would cause (Table 4 ). It intervenes in the healing of wounds [19].

Table 4: Proximate Composition and Energy Content of seeds of Momordica balsamina Values are means of triplicate determinations \pm standard error

\begin{tabular}{|c|c|}
\hline Constituents & Seeds \\
\hline Crude Protein N x 6.25\% & $8.75 \pm 1.00$ \\
\hline Crude Fiber\% & $1.95 \pm 0.03$ \\
\hline Fats/oil \% & $1.45 \pm 0.22$ \\
\hline Ash\% & $4.50 \pm 0.04$ \\
\hline Carbohydrates\% & $83.4 \pm 0.02$ \\
\hline Food energy g/cal & $381.5 \pm 0.11$ \\
\hline
\end{tabular}

Other vitamins such as niacin (vitamin $\mathrm{B}_{3}$ ), riboflavin (vitamin $B_{2}$ ) and thiamin (vitamin $B_{1}$ ) were also found in the seeds. The seeds of $M$. balsamina contain $0.21 \mathrm{mg} / 100 \mathrm{~g}$ of niacin, $0.30 \mathrm{mg} / 100 \mathrm{~g}$ of riboflavin and $0.09 \mathrm{mg} / 100 \mathrm{~g}$ of thiamin. Niacin is active in preventing the diseases pellagra which is characterized by skin and mucous membrane disorders as well as depression and confusion [20]. Thiamin is an essential factor in the function of the nervous system. Riboflavin favors body growth, catalyzing the chemical reactions needed for taking advantage of carbohydrates and proteins $[21,22]$.

Table 5: Inhibition Zone Diameter (IZD) ( $\mathrm{mm}$ ) of M. balsamina on the human pathogens, Values are mean of triplicate determination \pm standard error.

\begin{tabular}{|c|c|}
\hline Pathogens & M. balsamina seeds \\
\hline Proteus mirabilis & $8.0 \pm 0.03$ \\
\hline Klebsiella pneumoniae & $14.0 \pm 0.12$ \\
\hline Staphylococus aureus & $12.0 \pm 0.05$ \\
\hline Salmonella & $6.0 \pm 0.01$ \\
\hline Escherichia coli & $17.0 \pm 0.20$ \\
\hline
\end{tabular}

The results of the proximate composition showed that the seeds contain basic food nutrients such as protein, fats, carbohydrates and fiber. Crude protein was found to be $8.75 \%$ in the seeds of $M$. balsamina. Crude fiber content was found to be $1.95 \%$. Fiber cleans the digestive system, flushing the residue as efficiently and quickly as possible [14]. Fiber stimulates the gastrointestinal tract and acts as a laxative. In general, fiber appears to inhibit many cancers, especially colon cancer by binding the carcinogens and preventing them from entering the body while they pass through the system, [21]. The seeds contain $1.45 \%$ of fats/oil. The ash content was found to be 4.50 $\%$. They contain high amount of carbohydrates (83.4\%) and are rich in calories, the seeds have food energy of $381.5 \mathrm{~g}$ cal -1 


\section{Recent Advances in Petrochemical Science}

.The ethanolic extracts of the seeds of M. balsamina exhibited antibacterial activities on the pathogens tested as shown in (Table 5). The extracts inhibited all the tested organisms E.coli., K. pneumonia, S. aureus , P. mirabilis and Salmonina. The organisms' P. mirabilis and E. coli are the common cause of urinary tract infection and traveler's diarrhea $[23,24]$. Severe eye infections such as blepharo conjuctivities, corneal ulcers, abscesses, styes, dacryocystitis, orbital cellutitis and blebs are mainly caused by Staphylococus aureus and Pseudomonas aeruginosa [25]. The result of this analysis shows that seed of M. balsamina may be used as a natural antibiotic to treat eye and nose problems (Table 6). Natural antibiotics are preferred recently since the use of synthetic antibiotics has been reported to have side effects like hypersensitivity reactions, gastric disturbances, nephrotoxicity, etc.

Table 6: Minimum Inhibitory Concentration of the seeds of $M$. balsamina on the Pathogens (mm).

\begin{tabular}{|c|c|c|c|c|c|c|}
\hline Pathogens & $\mathbf{1 0 0}$ & $\mathbf{5 0}$ & $\mathbf{2 5}$ & $\mathbf{1 2 . 5}$ & $\mathbf{6 . 2 5}$ & MIC \\
\hline & \multicolumn{7}{|c|}{ Zone of Inhibition in mm } \\
\hline Proteus mirabilis & 8 & 5 & 3 & - & - & 25 \\
\hline $\begin{array}{c}\text { Klebsiella } \\
\text { pneumoniae }\end{array}$ & 14 & 10 & 6 & 3 & - & 12.5 \\
\hline $\begin{array}{c}\text { Staphylococus } \\
\text { aureus }\end{array}$ & 12 & 7 & 3 & 1 & - & 12.5 \\
\hline Salmonella & 6 & 3 & 2 & - & - & 25 \\
\hline Escherichia coli & 17 & 9 & 5 & 2 & - & $\mathrm{s}$ \\
\hline
\end{tabular}

\section{Conclusion}

The results of this investigation have revealed that the seeds of M. balsamina contain basic food nutrients such as protein, fats, carbohydrates, fiber etc. As rich sources of phytochemical, they can function as antioxidants, anti- inflammatory and anti-carcinogenic agents. The results of the antibacterial analysis indicate that the seeds of M. balsamina could be used as bactericidal agent for the treatment of venereal diseases, eye infection, nose infection, etc. The nutritional and health benefits of the seeds have proved the plant to be a potential source of useful drugs and quality food.

\section{Acknowledgement}

Authors are grateful to Mr Paul Nwosu of Soil Science laboratory, National Root Crops Research Institute, Umudike, Umuahia for his assistance in the laboratory work and to Dr A. Nmeregini of Taxonomy section, Forestry Department, Micheal Okpara University of Agriculture, and Umudike, Nigeria for authenticating our samples.

\section{References}

1. Burkill HM (1995) The useful Plants of West Tropical Africa. Royal Botanic Gardens, ( $\left.2^{\text {nd }} e d n\right)$, London, UK, pp. 456-596.

2. Hassan LG, Umar KJ (2006) Nutritional Value of Balsam Apple (Momordica balsamina L) Leaves. Pakistan Journal of Nutrition 5(6): 522-529.
3. Dalziel J (1937) The Useful Plants of West Tropical African, The Crown Agents for the Colonies, London, UK, pp. 52-560.

4. Otimenyin OS, Uguru OM, Akanubi BE (2008) Anti-diarrhea Effect of Aqueous Extract of Mormodica balsamina. Journal of Natural Products 1(2008): 36-45.

5. Hutchings A, Scott AH, Lewis G, Cunningham AB (1996) Zulu medicinal plants, an inventory. University of Natal press, Pietermaritzburg 60(9): 955

6. Roodt V (1998) the shell field guild bseries: part II. Common wild flowers of the Okavango delta, medicinal uses and nutritional value. Russell Friedman Book, Halfwan Hausa, South Africa.

7. Bandeira SO, Gaspar F, Pagula FP (2001) African ethanobotany and health care: Emphasis on Mozambique. Pharmaceutical Biology 39 (suppl 1): 70-73.

8. Okwu DE, Morah FNI (2006) Antimicrobial and Phytochemical evaluation of seed of Garcina Kola and Dennettia tripatala fruits. Journal of medicinal and Aromatic Plant Science p. 4.

9. Chikezie PC, Agomuo EN, Amadi EN (2008) Biochemistry Practical/ Research Method, A Fundamental Approach. Mega soft Publishers Nigeria (2): 8-20,

10. Onwuka GI (2005) Food Analysis and Instrumentation Theory and Practical. Naphthali Prints, Nigeria, pp. 95-96.

11. Ekundayo EO, Ezeogu LI (2006) Evaluation of antimicrobial activities of extracts of five plants used in traditional medicine in Nigeria. International J of Tropical Medicine 1(2): 93-96.

12. Okigbo RN, Omodamiro OD (2006) Antimicrobial effect of leaf extracts of pigean pea (Cajanus cajan (L)) on some human pathogens. Journal of Herbs, Spices and Medicinal Plant 12(1-2): 117-121.

13. Frantisek S, Hana S (1998) The Natural Guide to Medicinal Herbs and Plants. Tiger books International PLC, UK, p. 610.

14. Uchegbu RI, Okwu DE (2012) An Evaluation of the Phytochemical and Nutrient Composition of the Seeds and Stem bark of Detarium senegalense Gmelin. Journal of Natural Sciences Research 5(2): 107 $-111$.

15. Okwu DE, Omodamiro OD (2005) Effect of Hexane Extract and Phytochemical Content of Xylopia aethiopica and Ocimum gratissimum on uterus of guinea Pig. Bio-Research 3(2): 40-44.

16. Sodipo OA, Akiniyi JA, Ogunbamera JV (2000) Studies on certain characteristics of extracts from bark of Paninystalia macroceras (K Schum) Pierre ex Beille. Global Journal of Pure and Applied Sciences 6(1): 83-87.

17. Salem K (2000) How to Discover Abundant Health and Happiness. Morris Cerullo Mission to the entire World. San Diego, California, USA, p. 14.

18. Bruice PY ( 2007) Organic Chemistry ( $5^{\text {th }}$ edn). Pearson Education International, USA, p. 1319.

19. George D, Pamplona R (1998) New Lifestyle. Aravaca, 8/ 28040 Madrid, Spain, p. 513.

20. Hung HC, Josphipura KJ, Jiang R (2004) Fruit and Vegetable intake and risk of major chronic disease. J Natl Cancer Inst 96(21): 1577-1584.

21. Thakur GSI, Bag M, Sanodiya BS, Bhadouriya PM, Debnath GB, et al. (2009) Momordica balsamina: a medicinal and neutraceutical plant for health care management. Curr Pharm Biotechnol 10(7): 667-682.

22. Uchegbu RI, Mbadiugha CN, Ibe CO, Achinihu IO, Sokwaibe CE, et al. (2015) Antioxidant, anti-inflammatory and antibacterial activities of the seeds of Mucuna flagellipes. American Journal of Chemistry and Applications 2(5):116-119. 


\section{Recent Advances in Petrochemical Science}

23. Uchegbu RI, Akalazu JN, Ibe CO, Ahuchaogu AA, Amadikwa CU, et al (2016) Chemical Composition of the Stem Extract of Costus afer (Bush Cane) and Its Antimicrobial Activity. British Journal of Pharmaceutical Research 10(5): 1-9.

24. Singh S, Bhawani S, Rajesh S, Sahoo K, Subudhi E, et al. (2013) Chemical composition of turmeric oil (Curcuma longa L.) and its antimicrobial

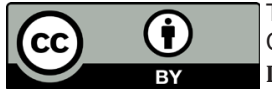

This work is licensed under Creative

Commons Attribution 4.0 Licens

DOI: $10.19080 /$ RAPSCI.2017.01.555569 activity against eye infecting pathogens. Journal of Essential Oil Research 23(6): 11-18.

25. Cosgrove SE, Vigliani GA, Campion M (2009) Initial low dose gentamicin for Staphyloccocus aureus bacteremia and endocarditis is nephrotoxic. Clin Infect Dis 48(6): 713-721.

Your next submission with Juniper Publishers
will reach you the below assets
- Quality Editorial service
- Swift Peer Review
- Reprints availability
- E-prints Service
- Manuscript Podcast for convenient understanding
- Global attainment for your research
- Manuscript accessibility in different formats
( Pdf, E-pub, Full Text, Audio)
- Unceasing customer service
Track the below URL for one-step submission
https://juniperpublishers.com/online-submission.php

